\title{
Simultaneous Administration of Statins and Pioglitazone Limits Tumor Growth in a Rat Model of Malignant Glioma
}

\author{
JORGE HUMBERTO TAPIA-PÉREZ ${ }^{1,2^{*}}$, ROBERT PREININGER $^{2 *}$, ELMAR KIRCHES $^{3}$, ANNEGRET REINHOLD $^{4}$, \\ JANA BUTZMANN ${ }^{2}$, SYLVIA PRILLOFF $^{5}$, CHRISTIAN MAWRIN $^{3}$ and THOMAS SCHNEIDER ${ }^{2}$ \\ ${ }^{1}$ Neurological Clinic, Julius-Maximilian-University, Wuerzburg, Germany; \\ ${ }^{2}$ Neurosurgical Clinic, Otto-von-Guericke University, Magdeburg, Germany; \\ ${ }^{3}$ Neuropathological Institute, Otto-von-Guericke University, Magdeburg, Germany; \\ ${ }^{4}$ Institute for Molecular und Clinical Immunology, Otto-von-Guericke University, Magdeburg, Germany; \\ ${ }^{5}$ Neuropsychological Institute, Leibniz Institute, Magdeburg, Germany
}

\begin{abstract}
Background/Aim: Statins are cholesterol reducers with considerable dose-dependent effect against glioma cells. The apoptotic effect could be increased by combining statins or by adding pioglitazone (PGZ). The last one is an antidiabetic drug, an agonist of the peroxisome proliferatoractivated receptor-gamma (PPARG). We used an animal model to test the effect of such combination in vivo and we investigated the changes on immunological processes. Materials and Methods: Thirty-three rats (F344/DuCrl) were anesthetized and glioblastoma (F98) cells were implanted stereotactically. Animals were randomized into four groups: i) control $(N=9)$; ii) intraperitoneal injection of $P G Z$ $10 \mathrm{mg} / \mathrm{kg} /$ day $(\mathrm{N}=8)$; iii) oral administration of atorvastatin (ATVS) $40 \mathrm{mg} / \mathrm{kg}$ and lovastatin (LVS) $50 \mathrm{mg} / \mathrm{kg}(\mathrm{N}=8) ; \mathrm{iv}$ ) oral administration of ATVS $40 \mathrm{mg} / \mathrm{kg}, \mathrm{LVS} 50 \mathrm{mg} / \mathrm{kg}$ and PGZ $5 \mathrm{mg} / \mathrm{kg} \quad(\mathrm{N}=8)$. Treatment was started at $3 \mathrm{rd}$ postoperative day and continued for 14 days. The animals were followed-up for 30 days after start of therapy. Survival time, tumor volume, proliferation rate, counts of peripheral and tumor infiltrating leukocytes were compared. Results: No difference of survival time or incidence of neurological deficits was observed. The combination of statins with PGZ led to a significant reduction in tumor volume by approximately $40 \%$ $(p<0.05)$, statins combination was less effective and PGZ alone did not affect tumor volume. The groups treated with statins displayed significantly lower counts of peripheral
\end{abstract}

\footnotetext{
*These Authors contributed equally to this work.

Correspondence to: Tapia-Pérez J. Humberto, MD, Neurological Clinic and Policlinic, University Wuerzburg Josef-Schneider-Straße 11 D-97080 Wuerzburg, Germany. Tel: +49 93120124617, Fax: +49 93120123697, e-mail: tapia_j@ukw.de
}

Key Words: Glioblastoma, statin, thiazolidinediones, macrophages.
$\mathrm{CD}^{+}, \mathrm{CD}^{+}$and $\mathrm{CD} 8^{+}$T-cells and lower tumor associated CD68-positive cells $(p<0.01$, in respect to controls or PGZ alone). The proliferation rate was not statistically different. No relevant toxic effects were observed. Discussion: Statins and PGZ are well-tolerated in rats and produced a significant tumor reduction, while an impact on neurological deficits or survival improvement could not be demonstrated. The reduction of infiltrating macrophages by using statins and PGZ should be further studied.

Glioblastoma (GB) is the most frequent malignant brain tumor and has a very poor prognosis. Despite the best current treatment, including surgical resection and radiochemotherapy, the median overall survival and progression-free intervals remain short ( $<24$ months) (1). Statins are inhibitors of the 3-hydroxy-3-methylglutaryl-CoA reductase (HMGCR) and they reduce serum cholesterol levels as well as the mevalonate and prenoids synthesis pathways $(2,3)$. Prenoids are required for post-translational isoprenylation of GTPases such as RAS and RHO (4), then statins regulate several molecular pathways and they may lead to an anti-tumor response (5). On the other hand, thiazolidinediones (TDZ) are agonists of the peroxisome proliferator-activated receptor gamma (PPARG), which besides its primary use in diabetic patients, displays a proapoptotic activity as well $(6,7)$. Experimental studies with statins (8) and thiazolidinediones (9) in cell cultures of malignant glioma have confirmed the existence of a relevant induction of apoptosis.

In a mouse model of glioma, lovastatin induced apoptosis without increasing the effect of radiation; the low drug concentration in brain parenchyma was provided as explanation of the failure (10). Another study in animals suggested that low and higher doses of simvastatin lead to different effects (11). Regarding thiazolidinediones, there are reports about the synergistic effect against glioma in 
combination with 6-OH-11-O-hydroxyfenantrene or interleukin-2 (IL2) $(6,12-14)$. Despite the fact that PGZ crosses the blood brain barrier, its oral administration reaches only in lower concentrations in cerebral tissue (15).

In short, statins and thiazolidinediones are attractive drugs for glioma therapy but their use is limited by low drug concentration in target tissue and potential side-effects. The synergism of statins and thiazolidinediones has been prior postulated and may lead to an improvement of the effect at lower doses $(16,17)$. Our group has reported the different anti-tumor effects of synthetic and natural statins as well as the synergism in combination with pioglitazone in cell cultures of malignant glioma (17). Based on these findings we conducted a study using an established rat model of glioblastoma to assess the feasibility of a combination of statins and TDZ for therapy of glioblastoma.

\section{Materials and Methods}

Animal model and surgery. We implanted cells of the glioblastoma cell line F98 in Fischer-rats (F344/DuCrl). F98 cells were grown in Dulbecco's modified Eagle's medium (DMEM; PAN-Biotech, Aidenbach, Germany) with $1 \%$ penicillin/streptomycin and $10 \%$ fetal calf serum. In vivo, these tumor cells formed a solid tumor with morphology and histology resembling that of human glioblastoma. They are especially an attractive model to investigate the mechanisms underlying glioma resistance to immunotherapy because of its weakly immunogenic character (18). Rats were anesthetized with an intraperitoneal injection of ketamine $(80 \mathrm{mg} / \mathrm{kg}$ of weight) and intramuscular injection of xylosin $(12 \mathrm{mg} / \mathrm{kg}$ of weight). A total of $1 \times 10^{4} \mathrm{~F} 98$ cells dispersed in $3 \mu \mathrm{l} \mathrm{PBS}$, were implanted stereotactically into the right nucleus caudatus of the animal using a stereotactic frame under a surgical protocol approved by the ethical commission of studies in animals in Halle (Saale), Sachsen-Anhalt, Germany. Thirty-three animals were used for the survival study. Animals were euthanized when they were moribund, displayed neurological deficits or $20 \%$ weight reduction from basal status or after a follow-up time of 30 days following therapy onset, according to the protocol approved by the ethics board.

Therapy groups. Rats were randomized into four treatment groups: 1 . control (water, oral), 2. pioglitazon $(10 \mathrm{mg} / \mathrm{kg} /$ day intraperitoneal; Actos, Takeda, Germany), 3. atorvastatin ( $40 \mathrm{mg} / \mathrm{kg}$, oral; Sortis, Pfizer, Germany) and lovastatin $(50 \mathrm{mg} / \mathrm{kg}$, oral; Lovabeta, betapharm Arzneimittel, Germany), and 4 atorvastatin $(40 \mathrm{mg} / \mathrm{kg}$, oral) plus lovastatin $(50 \mathrm{mg} / \mathrm{kg}$, oral) and pioglitazon $(5 \mathrm{mg} / \mathrm{kg}$, oral). For oral administration a water-base gel was used (solid drink from Triple A Trading, HG Tiel, the Netherlands), starting on postoperative day three. A specific weight-adapted gel-based combination of oral administrated drugs was consumed ad libitum. The application was continued for 14 days. Animals were narcotized and sacrificed after heart puncture based on the above-mentioned criteria. Their brains were excised and histologic examinations of brain sections were performed.

Tumor volume. Brains were stored in formalin for a day and subsequently dehydrated in $70 \%$ alcohol for three days and betted in paraffin. Brains were then cut into 2-4 $\mu \mathrm{m}$ serial sections on a microtome (Microm SM200R; Leica, Wetzlar, Germany). To determine tumor size, sections were stained with haematoxylin and eosin in anatomical order. The area of the sections was determined using Image J software. An ellipsoid's volume approach was used for volume calculation. $\mathrm{L}$ was the largest diameter and $\mathrm{W}$ (width) is perpendicular to $\mathrm{L}$. The parameters were substituted in the formula: $\mathrm{V}=\pi / 6 * \mathrm{~L} * \mathrm{~W}^{2}$ and the resulting tumor size expressed in $\mathrm{mm}^{3}$. Volume comparisons were performed in those rats with similar survival periods ( $\mathrm{N}=4$ each group).

Proliferation assay. The proliferations rate was assessed by staining with the antibody against Ki-67 according to the manufacturer's instructions using the protocol for paraffin-embedded tissue sections (dilution 1:100, Dako ${ }^{\circledR}$, Hamburg, Germany). Positive cells were counted and presented as percent of total cells.

Immunohistochemistry for identification of tissue leukocytes. Further sections were stained for identification of $\mathrm{CD}^{+}$and $\mathrm{CD} 8^{+}$ lymphocytes; $\mathrm{CD} 25^{+}$activated T- lymphocytes and macrophages $\mathrm{CD}^{+} 8^{+}$. Primary antibodies for CD4, CD8, CD25 and CD68 were mouse anti Rat, Bio-Rad AbD Serotec, Puchheim, Germany. Streptavidin/HRP was secondary antibody (DAKO, Hamburg, Germany). Slides were counterstained with hematoxylin and examined microscopically. Images were digitally recorded under $40 \times$ objective. The histological sections of four animals (with similar survival time) in each group were stained and 20 quadrants were divided. Cell counts were expressed as mean of cells/field.

Lymphocytes subpopulations and TGF-beta 1 analysis. Counts of lymphocytes including B-, (CD45RA)- and T-lymphocytes (CD3), T-lymphocyte subclasses $\left(\mathrm{CD}^{+}, \mathrm{CD}^{+}\right.$and $\left.\mathrm{CD} 3^{+}, \mathrm{CD}^{+}\right)$, activated T-lymphocytes $\left(\mathrm{CD} 3^{+} / \mathrm{CD} 25^{+}\right.$or $\left.\mathrm{CD}^{+} / \mathrm{MHCII}^{+}\right)$and Natural Killer cells $\left(\mathrm{NK}, \mathrm{CD} 161^{+}\right)$were determined using the respective antibody cocktails and a flow cytometer FACSCalibur (BD Biosciences, Heidelberg, Germany). TGF-beta 1 was measured as well (R \& D Systems, Wiesbaden, Germany). All the measurements were achieved from blood samples collected during heart puncture.

Muscular and hepatic toxicity. Elastic-van-Gieson and Gomori trichrome staining techniques in muscle tissue were used in order to identify toxicity. Liver sections were stained with haematoxylin and eosin to inspect for histo-architectural changes as well. Sections were assessed in a blinded manner with a microscope.

Statistical analysis. An SPSS v.22 (Armonk, NY: IBM Corp.) analytical software was used; all data were expressed as mean \pm SD. Tumor volumes, counts of infiltrating cells and peripheral white blood cell counts were analyzed by one-way ANOVA followed by multiple comparisons of the least significant difference (LSD). For survival analysis Kaplan-Meier curves were constructed and logrank test was applied for comparing differences. Statistical significance was assumed for $p<0.05$.

\section{Results}

Survival and therapy tolerance. The median survival time of all animals was 26 days. No statistical difference was found between the groups studied. Figure 1 displays the survival curves of the therapy groups. One rat in the pioglitazone group and another in the group with combined statin therapy plus pioglitazone group achieved the maximal observation time (30 days) without neurological deficits or evidence of impairment 


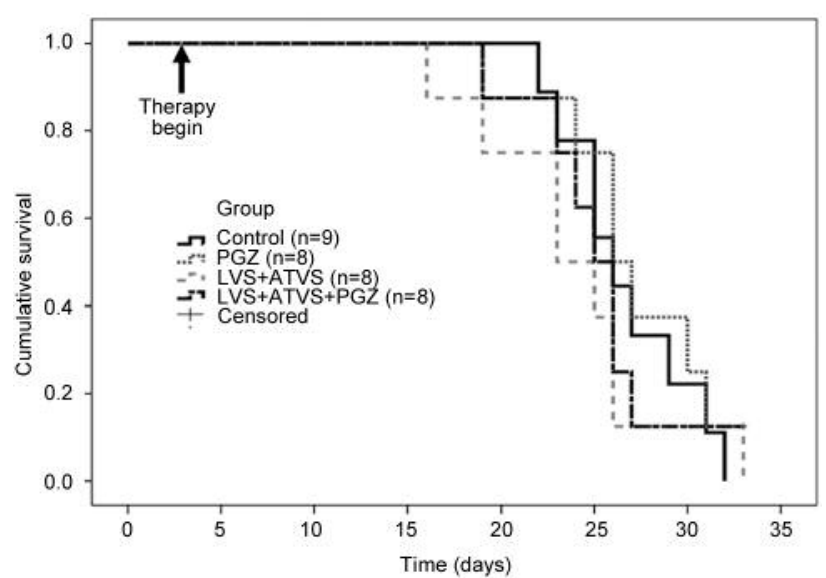

Figure 1. Kaplan-Meier curves comparing survival times between therapy groups. ATVS: Atorvastatin, LVS: lovastatin, PGZ: pioglitazone.

of general status. The most common collateral effect of the statin therapy was diarrhoea within the first days after beginning of therapy, which persisted no longer than 2 days.

Volume measurements. The volume comparisons were performed in the brain of animals with same or similar survival time. Compared to the control, only the group treated with lovastatin and atorvastatin plus pioglitazone displayed a statistically significant volume reduction $\left(37.5 \pm 12.5 \mathrm{~mm}^{3} v \mathrm{~s}\right.$. $\left.88.9 \pm 24.83 \mathrm{~mm}^{3}, p=0.002\right)$. Pioglitazone alone $(83.4 \pm 17.9$ $\left.\mathrm{mm}^{3}\right)$ in comparison to controls $(p=0.70)$ and statin combination $\left(67.1 \pm 33.7 \mathrm{~mm}^{3}, p=0.29\right)$ were not statistically different (Figure 2). The addition of pioglitazone to the combined statin therapy provided an increment of tumor reduction in comparison to pioglitazone alone $(p=0.007)$ and a slight difference in comparison to statin combination $(p=0.065)$.

Proliferations assay. The rate of proliferating cells was lower among the groups treated with statins. The lowest mean count of Ki67-positive cells was in the statin group with pioglitazone $(34.8 \pm 19.9 \%)$, followed by the group with statins combination $(39.3 \pm 5.5 \%)$. The highest rate of positive cells was in the control group $(51.5 \pm 14.8 \%)$ and near to that was the group treated exclusively with pioglitazone $(47.2 \pm 10.04 \%)$, however no statistically significant differences were found between the groups $(p=0.34)$.

Tumor-infiltrating leukocytes. The counts of infiltrating $\mathrm{CD}^{+}$, $\mathrm{CD}^{+}{ }^{+}$and $\mathrm{CD} 25^{+}$cells were not different between groups. The mean values of infiltrating $\mathrm{CD} 68^{+}$cells were significantly lower in the groups of statin combination with or without pioglitazone in comparison to pioglitazone alone or controls $(p<0.01)$. The mean count of $\mathrm{CD}^{+} 8^{+}$cells in controls was $18.08 \pm 3.48$ cells/field and $17.11 \pm 3.3$ cells/field in the group

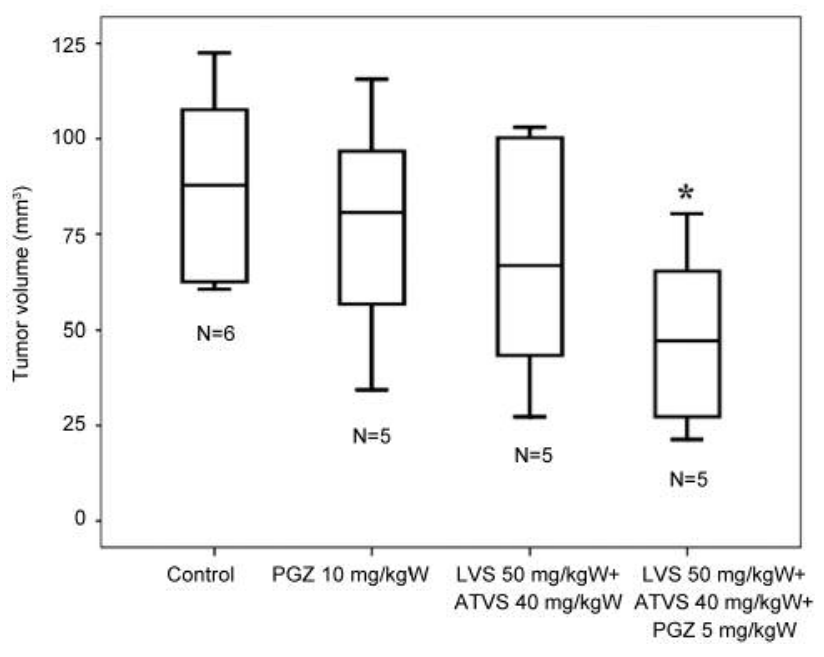

Figure 2. Comparisons of tumor volume between groups. ATVS: Atorvastatin, LVS: lovastatin, PGZ: pioglitazone. An asterisk indicates p-value less than 0.05 .

with pioglitazone alone $(p=0.56)$. The CD68-positive cells in the statin group without pioglitazone was $9.98 \pm 0.89$ cells/field and with pioglitazone was $11.52 \pm 1.34$ cells/field $(p=0.48)$. Figure 3 displays the above observations.

Circulating white cell population and TGF-beta 1 analysis. The absolute counts of leukocytes, monocytes and granulocytes were not different between groups. The absolute numbers of total $\mathrm{CD}^{+}$as well as $\mathrm{CD}^{+} \mathrm{CD}^{+}$and $\mathrm{CD} 3^{+} \mathrm{CD} 8^{+}$cells were statistically significant different between groups (Figure 4). Further differences were found in a post hoc analysis; the absolute number of lymphocytes was lower in the lovastatin and atorvastatin $(1,125.0 \pm 411.3 \mathrm{cells} / \mu \mathrm{l})$ group compared to controls $(2,875 \pm 953.5$ cells $/ \mu \mathrm{l}, p=0.018)$, but it was not different compared to other therapy groups. Combination of statins with or without pioglitazone presented lower cell counts of CD3+ $(823.25 \pm 389.54$ cells $/ \mu \mathrm{L}$ and $591.0 \pm 206.3$ cells $/ \mu \mathrm{L})$, $\mathrm{CD}^{+} \mathrm{CD}^{+} \quad(487.5 \pm 231.06$ cells $/ \mu \mathrm{L}$ and $383.25 \pm 158.3$ cells $/ \mu \mathrm{L})$, and $\mathrm{CD}^{+} \mathrm{CD}^{+}(317.75 \pm 165.99$ cells $/ \mu \mathrm{L}$ and $225.0 \pm 72.32$ cells $/ \mu \mathrm{L})$ in comparison to controls $(1870.2 \pm 665.3$ cells $/ \mu \mathrm{L}, 1221.0 \pm 408.2$ cells $/ \mu \mathrm{L}$, and $683.2 \pm 263.7$ cells $/ \mu \mathrm{L})$ but do not differ from pioglitazone alone $(1,020.0 \pm 819.6$ cells $/ \mu \mathrm{L}$, $662.7 \pm 556.0$ cells $/ \mu \mathrm{L}$, and $368.0 \pm 280.1$ cells $/ \mu \mathrm{L})$. Lovastatin and atorvastatin combination's group displayed the lowest counts of $\mathrm{CD}^{+} \mathrm{MCH}-\mathrm{II}^{+}$cells $(29.5 \pm 11.23$ cells $/ \mu \mathrm{L})$, but this count was only significant in comparison to controls $(66.75 \pm 333$ cells $/ \mu \mathrm{L}) . \mathrm{CD} 45 \mathrm{RA}^{+}$cells, $\mathrm{NKs}$, and CD ${ }^{+} \mathrm{CD} 25^{+}$ cells were not different between groups (Figure 4$)$. The levels of TGF-beta 1 in plasma did not show differences.

Muscular and hepatic toxicity. The qualitative histological examinations did not show any evidence of toxicity (Figure 5). 

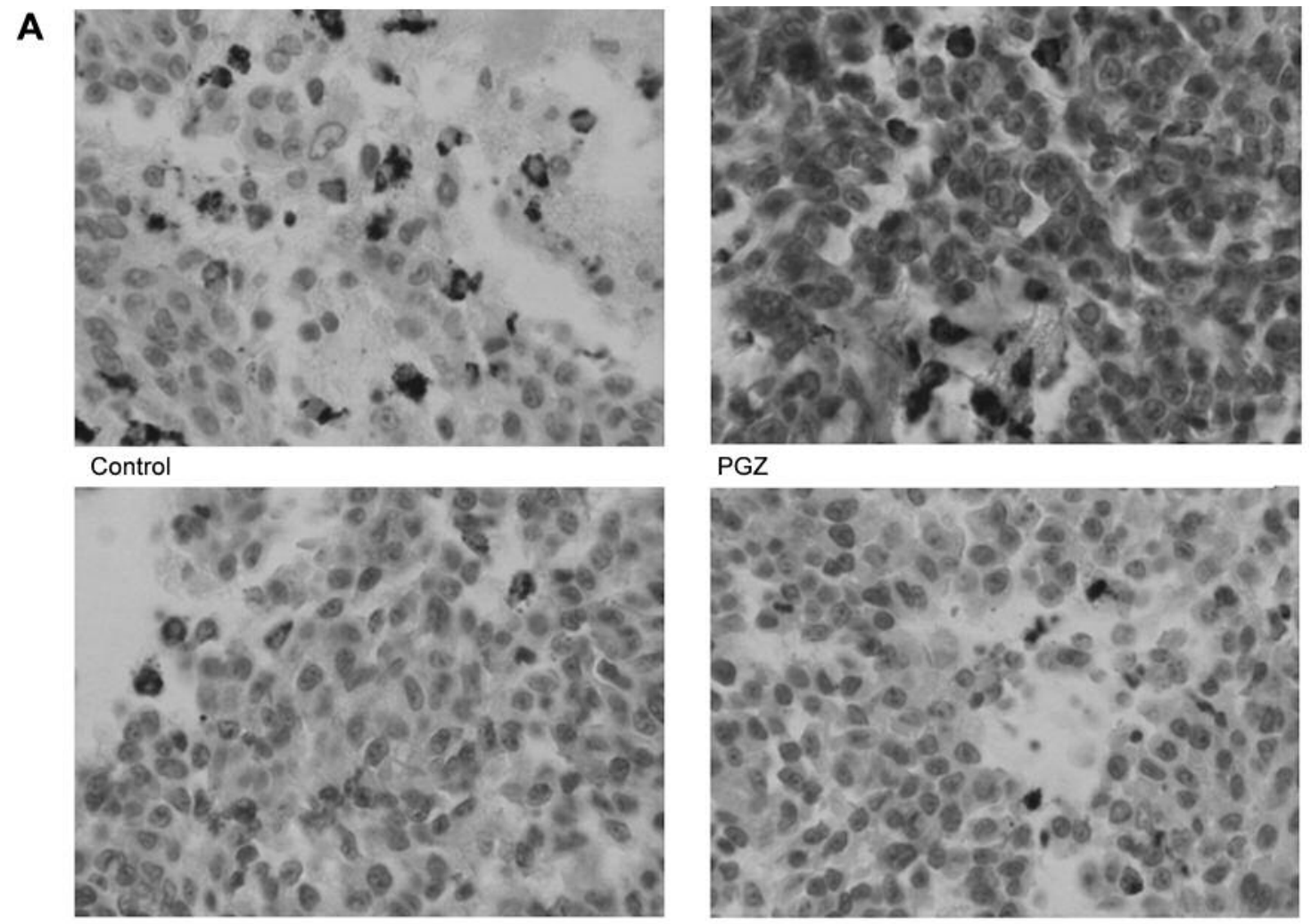

PGZ

LVS+LVS

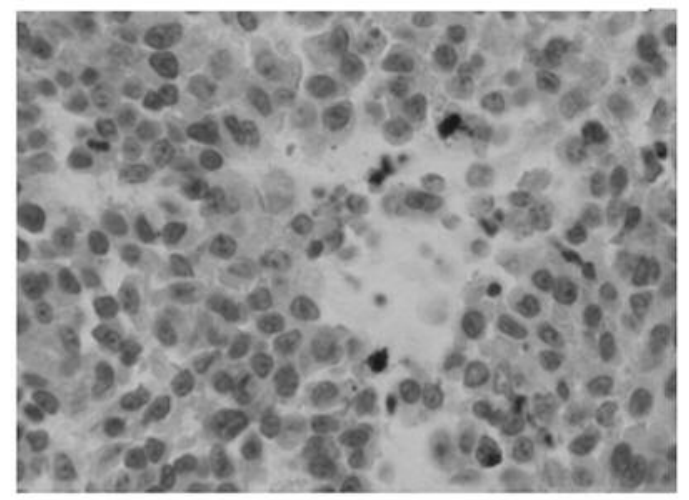

LVS+ATVS+PGZ

$\mathbf{B}$

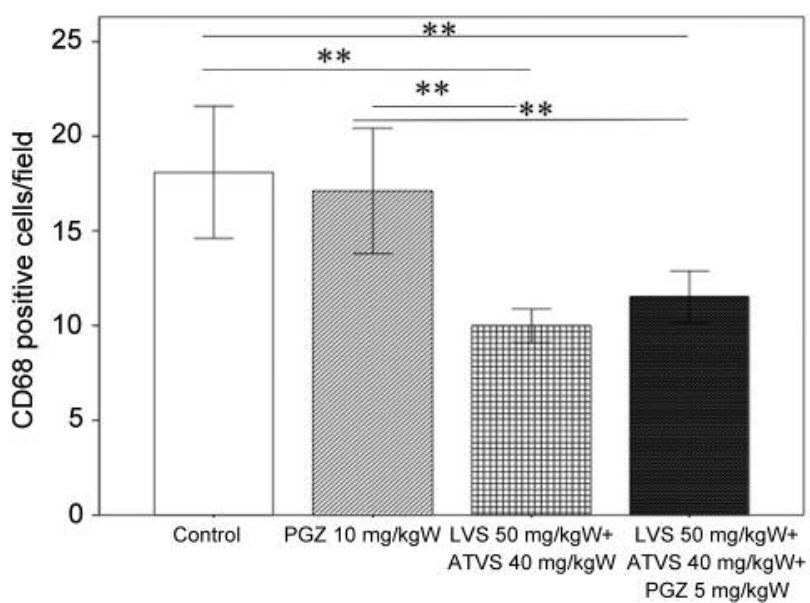

Figure 3. Comparison of $\mathrm{CD} 68^{+}$cell counts between groups of treatment ATVS: Atorvastatin, LVS: lovastatin, PGZ: pioglitazone. Two asterisks indicate p-value less than 0.01 .

\section{Discussion}

In this study we attempted to delimit the effects of a combined therapy with a natural and a synthetic statin. Based on the findings of Gabrys et al. we used lovastatin at 50 $\mathrm{mg} / \mathrm{Kg}$, a dose which was well tolerated up to 1 month, led to a modest reduction of tumor volume, but it was insufficient to increase the effect of radiation (10). Bababeygy et al. tested $1 \mathrm{mg} / \mathrm{kg} / \mathrm{day}$ and $10 \mathrm{mg} / \mathrm{kg} / \mathrm{day}$ of simvastatin and found an increased necrosis and apoptosis without an effect on tumor volume (11). Until today, simvastatin is recognized as the statin with the highest rate 


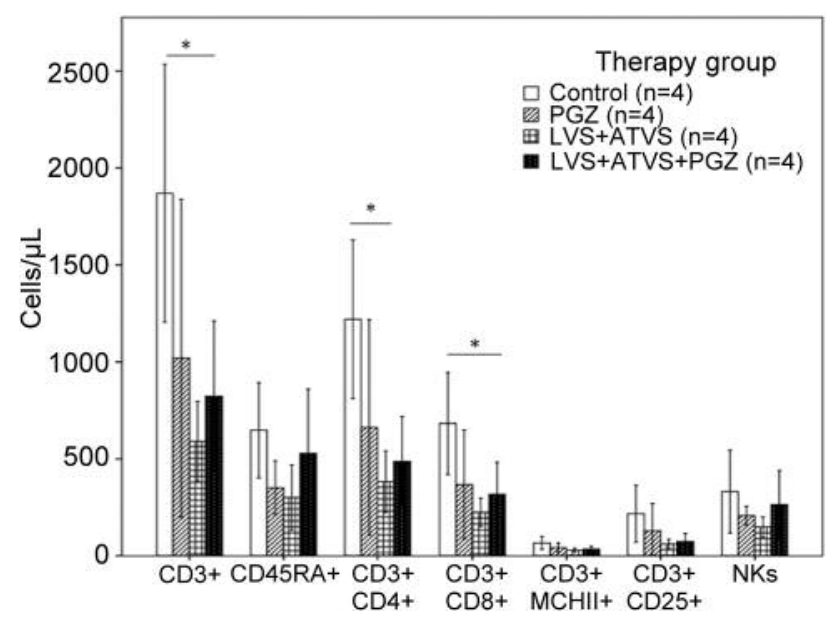

Figure 4. Absolute counts of peripheral leucocytes. ATVS: Atorvastatin, LVS: lovastatin, PGZ: pioglitazone. An asterisk indicates p-value less than 0.05 .

of collateral effects and therefore it is expected that a higher dose may lead to more adverse effects (19). In this context, simvastatin would not be the best choice for a statin-based therapy in humans. We have demonstrated in cell cultures of glioma that different types of statins display different effects on tumor cells and that not all (e.g. pravastatin) are convenient for glioma-therapy (16). Moreover, by combining some statins (e.g. natural and synthetic) it is possible to increase the anti-tumor effect. It is recognized that statins possess several pharmacological variations (5). While pravastatin is administered as the readily-active drug, lovastatin and simvastatin are administered as inactive lactones, which must be metabolized (20). Because of their chemical structure atorvastatin and lovastatin are more efficient in terms of required dose to decrease HMG-CoA reductase activity (5). The lipophilicity/hydrophilicity rate is another critical factor for the observed pleiotropic effects of statins $(20,21)$. Moreover, statins display a dual effect on angiogenesis regulation, low doses promote it while higher doses inhibit it; atorvastatin may inhibit inflammatory angiogenesis at both low and high doses (22). Lovastatin and atorvastatin use in combination, did not demonstrate reduction neither in tumor size nor in proliferation. Even though the higher doses applied were well tolerated, there was no detectable differences in survival. A non-randomized trial accomplished in 1998 using lovastatin in patients with glioma WHO grade III-IV reported a well-tolerated therapy with only minimal effect on response/survival (23). Considering the above-mentioned information, statin as a single-therapy might not be sufficient against glioma and thus, a more aggressive approach is needed.

A non-randomized phase II study in pediatric patients with malignant brain stem tumors evaluated the effectiveness of chemotherapeutic courses consisting of thalidomide and fluvastatin ( $8 \mathrm{mg} / \mathrm{kg} /$ day orally every $24 \mathrm{~h}$, days 1-14) combined with carboplatin and vincristine every 14 days followed by radiotherapy. This complex scheme caused an increase of survival and a tumor reduction (24) indicating that statins could be good partners in order to increase the anti-tumor effects of other drugs. Mercurio et al. assessed the combined therapy of celecoxib (200 mg twice daily) and fluvastatin (2-8 $\mathrm{mg} / \mathrm{kg} /$ day for 2 weeks every 4 weeks) in a patient with refractory relapsing multifocal picotitic astrocytoma. After 16-months therapy, they found a decrease of contrast enhancing areas (25). In cell cultures, Yao et al. as well as Tapia et al. demonstrated the effectiveness of combining statin and TDZ, especially pioglitazone $(16,17)$. In vivo studies showed that TDZ could induce tumor reduction $(6,14)$, however the main limitation of the oral use of TDZ as a single therapy lies in the high dose, which could not be applied in humans (15). Even at lower doses, TDZ may exhibit toxicity and because of that TDZ have been withdrawn from the market of many countries or are under strict control (26). We have previously found that the addition of pioglitazone to a combined statin regime may substantially increase the cytotoxicity towards glioma cells and it allowed dose reduction for both drugs while we did not find any increased toxicity towards astrocytes or fibroblasts $(16,27)$. In this study, we showed a significant enhancement of tumor reduction by combining statins and pioglitazone in our animal model. This effect is statistically superior to a treatment with pioglitazone alone and slightly better than a combined statin schedule without pioglitazone. However, we could not detect a survival benefit. A possible explanation for it, could be the duration of the therapy since it was restricted to 14 days. This limited schedule might be effective for slowing down tumor growth but not enough to demonstrate an improvement in survival during this short observational period.

Induction of apoptosis, regulation of cell migration and angiogenesis might represent the main attack points of statins (8) and these effects might be increased by PPARG agonists $(16,28)$. The proliferation inhibition is dose-dependent and here we showed that statins are able to reduce the proliferations rate, but the addition of pioglitazone did not show significant advantages.

The immunological effects of statins are widely described (29). Statins interfere with the required interaction between MHC (class I and II) and CD8/CD4 receptors to achieve a successful T-cell activation (30). They inhibit activation of co-stimulatory molecules (CD80, CD86, CD40) and of the nuclear factor kappa-beta $(\mathrm{NFKB})$ as well $(31,32)$. The integrin subunit beta 2 (ITGB2/ CD18) belongs to the B2 integrin subfamily and conforms with the alpha $\mathrm{L}$ unit (CD11a) a heterodimeric receptor, the lymphocyte functionassociated antigen-1 (LFA-1) that plays a central role in 
A

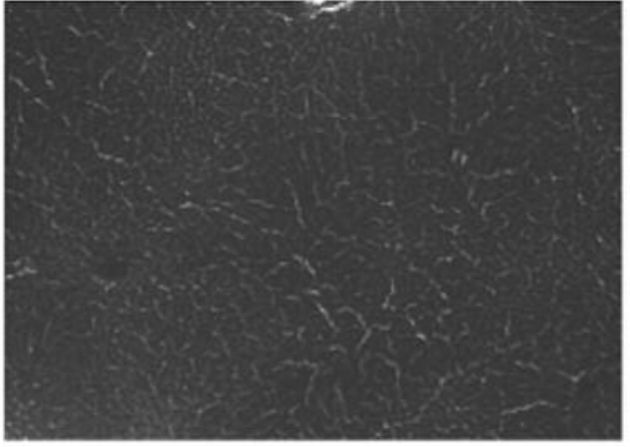

Control

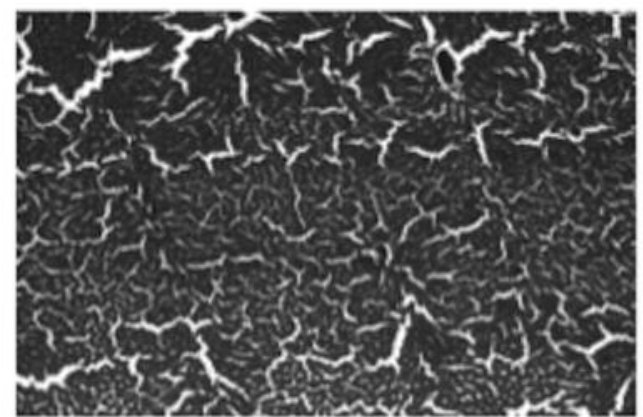

LVS+LVS

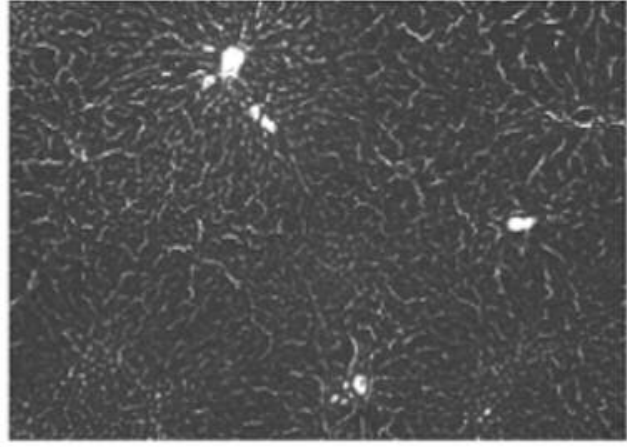

PGZ

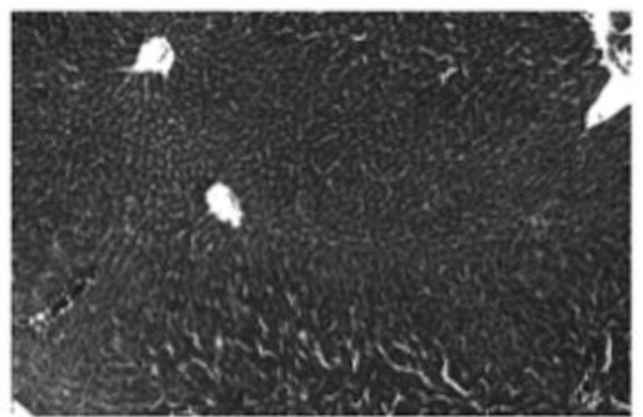

LVS+ATVS+PGZ

B

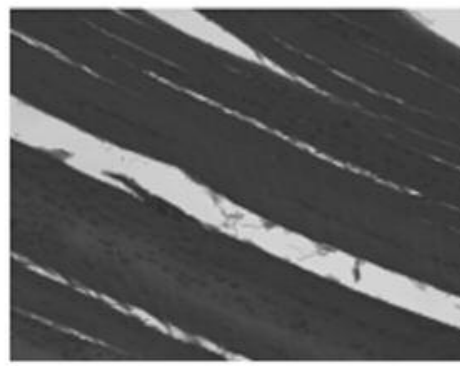

Control

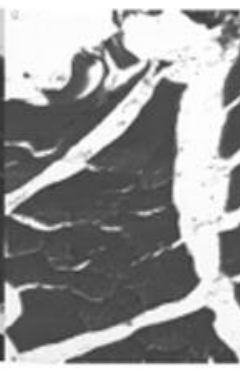

LVS+LVS

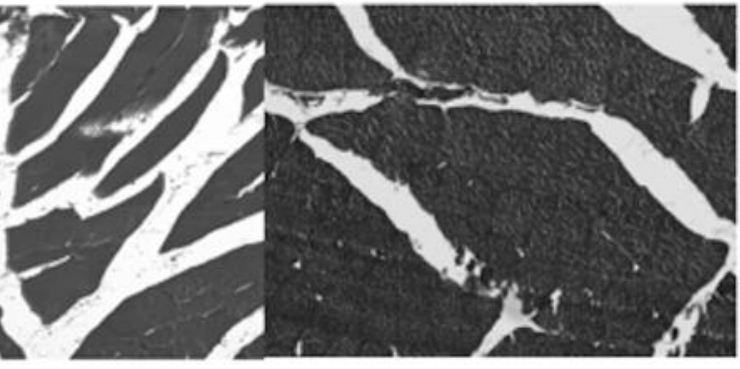

LVS+ATVS+PGZ

Figure 5. Histological examinations for toxicity in (A) liver and (B) muscle.

lymphocyte homing and leukocyte trafficking (33). Lovastatin blocks LFA-1 by binding to the allosteric site of the extracellular domain I on the L chain (known as the lovastatin site). The activation of other adhesion molecules in monocytes and T-cells might be inhibited by statins, e.g. ICAM1, ITGAM, and ITGA2 (33). While in literature an immunosuppressive effect of statins is mostly suggested; other authors have proven that NK cells in humans could also be activated (34). The specific immunological role of statin in glioma is not clear. In this study we assessed the immunological effects of statins in two ways: first, by circulating leucocytes analysis and second, by infiltrating leucocytes analysis. The measurements of white cells in blood evidenced the existence of a diminution of circulating $\mathrm{CD}^{+}$ and $\mathrm{CD} 8^{+}$T-cells. These changes may reflect a repopulation of T-cells, despite the fact that the counts of $\mathrm{CD} 4^{+}$and $\mathrm{CD} 8^{+}$ cells intra-tumorally were not different between groups. In tumor, we found that the infiltrating $\mathrm{CD}^{+} 8^{+}$cells, namely macrophages, were significantly lower in the statin groups. The relevance of such finding is the fact that increased number of macrophages have been described as a factor related to tumor progression (35). In our study, we did not approach the different types of macrophages neither the effect on microglia, further studies should address these issues.

Epidemiological data have provided more insights about the effect of statins on cancer. Nielsen et al. suggested that 
patients under statin therapy who received cancer diagnosis and continued the statin therapy had a diminished risk to die, independently of the cardiovascular benefit that it may additionally have (36). A case-control study including 517 patients with glioma and 400 control-patients, showed that simvastatin and lovastatin displayed an inverse association with the probability to develop a glioma (51\% and $47 \%$ risk reduction, respectively) and the effect was directly correlated to the overall time using the medicament (37). The above findings are reinforced by another a case-control study based on a population register in Denmark, showing among statin users a reduction of $12 \%$ in glioma development, especially if the statin was applied for more than 5 years (reduction increased to 24\%) (38). Other analysis from the same group, suggested that the longer and intensive use of statin is associated with a reduced risk of death in patients with glioblastoma (39). A randomized, double blind trial assessed the effect of $40 \mathrm{mg}$ atorvastatin administered in patients who underwent surgical resection of a glioma (40). The trial demonstrated that low dose of atorvastatin significantly reduced the plasma levels of matrix metalloproteinase 9 (MMP9) two weeks postoperatively and improves the Karnofsky performance index 2-months after surgery. All these evidences provide insights that a low-dose therapy over a long time might represent a potential therapy of gliomas.

There are a lot of questions regarding the cerebral pharmacology of statins (41). In the animal model studied, we used an oral therapy applied through a water-based gel, so it is possible that a lower dose was delivered. Similar plasmatic bioavailability of atorvastatin as capsule or solution has been described but the data regarding their corresponding distribution in brain tissue are missing (42). Spare information is available about the transport of statins through the blood brain barrier, where lovastatin seems to be superior to simvastatin and pravastatin (43) while information about atorvastatin is not available yet.

In short, the weak points of this study could be resumed as follow: the observation time was limited to 30 days after the onset of therapy and even though the sample size was significantly increased, a positive result was not possible to be identified. It is possible that a longer observation time could facilitate the detection of survival differences. Also, since the duration of the treatment was limited to 14 days and the oral administration of the drugs was allowed ad libitum consume, this could lead to lower effective doses. We did not assess any group treated only with one statin. We did not perform further examinations for classifying macrophages and we did not approach further immunological mechanisms. Finally, we did not explore molecular mechanisms of muscular or hepatic toxicity.

Our data, suggested strongly that statin and pioglitazone may act synergistically against glioblastoma by limiting tumor growth and macrophage invasion The role of statins in neuro-oncology remains to be elucidated. The tolerability of an inclusion of statins in the schedule of currently applied standard chemotherapy of malignant glioma (temozolomide) should be assessed. Preliminary data (not shown) suggest the synergism of statin, pioglitazone and temozolomide. Phase I trials for dose titration and safety evaluation are needed now.

\section{References}

1 Stupp R, Hegi ME, Mason WP, van den Bent MJ, Taphoorn MJ, Janzer RC, Ludwin SK, Allgeier A, Fisher B, Belanger K, Hau P, Brandes AA, Gijtenbeek J, Marosi C, Vecht CJ, Mokhtari K, Wesseling P, Villa S, Eisenhauer E, Gorlia T, Weller M, Lacombe D, Cairncross JG and Mirimanoff RO; European Organisation for Research and Treatment of Cancer Brain Tumour and Radiation Oncology Groups; National Cancer Institute of Canada Clinical Trials Group: Effects of radiotherapy with concomitant and adjuvant temozolomide versus radiotherapy alone on survival in glioblastoma in a randomised phase III study: 5-year analysis of the EORTC-NCIC trial. Lancet Oncol 10: 459-466, 2009. http://www.sciencedirect.com/ science/article/pii/S1470204509700257

2 Amarenco P, Bogousslavsky J, Callahan A 3rd, Goldstein LB, Hennerici M, Rudolph AE, Sillesen H, Simunovic L, Szarek M, Welch KM and Zivin JA; Stroke Prevention by Aggressive Reduction in Cholesterol Levels (SPARCL) Investigators: Stroke prevention by aggressive reduction in cholesterol levels (SPARCL) investigators. High-dose atorvastatin after stroke or transient ischemic attack. N Engl J Med 355: 549-559, 2006. http://www.nejm.org/doi/full/10.1056/NEJMoa061894\#t=article

3 Fletcher B, Berra K, Ades P, Braun LT, Burke LE, Durstine JL, Fair JM, Fletcher GF, Goff D, Hayman LL, Hiatt WR, Miller NH, Krauss R, Kris-Etherton P, Stone N, Wilterdink J, Winston M; Council on Cardiovascular Nursing; Council on Arteriosclerosis, Thrombosis, and Vascular Biology; Council on Basic Cardiovascular Sciences; Council on Cardiovascular Disease in the Young; Council on Clinical Cardiology; Council on Epidemiology and Prevention; Council on Nutrition, Physical Activity, and Metabolism; Council on Stroke; Preventive Cardiovascular Nurses Association: Managing Abnormal Blood Lipids: A Collaborative Approach. Circulation 112: 3184-3209, 2005. http://circ.ahajournals.org/content/112/20/3184

4 Bouterfa HL, Sattelmeyer V, Czub S, Vordermark D, Roosen K and Tonn JC: Inhibition of Ras farnesylation by lovastatin leads to downregulation of proliferation and migration in primary cultured human glioblastoma cells. Anticancer Res 20: 27612761,2000 . http://www.pubfacts.com/detail/10953355/Inhibitionof-Ras-farnesylation-by-lovastatin-leads-to-downregulation-ofproliferation-and-migration

5 Gazzerro P, Proto MC, Gangemi G, Malfitano AM, Ciaglia E, Pisanti S, Santoro A, Laezza C and Bifulco M: Pharmacological actions of statins: a critical appraisal in the management of cancer. Pharmacol Rev 64: 102-146, 2012. http://pharmrev. aspetjournals.org/content/64/1/102.long

6 Grommes C, Landreth GE, Sastre M, Beck M, Feinstein DL, Jacobs AH, Schlegel U and Heneka MT: Inhibition of in vivo glioma growth and invasion by peroxisome proliferator-activated receptor gamma agonist treatment. Mol Pharmacol 70: 1524-1533, 2006. http://molpharm.aspetjournals.org/content/70/5/ 1524.long 
7 Lichtor T, Spagnolo A, Glick RP and Feinstein DL: PPAR-y thiazolidinedione agonists and immunotherapy in the treatment of brain tumors. PPAR Res 2008:547470, 2008. https://www.ncbi.nlm. nih.govpmc/articles/PMC2396217/

8 Tapia-Pérez JH, Sanchez-Aguilar M and Schneider T: The role of statins in neurosurgery. Neurosurg Rev 33: 259-270, 2010. http://link.springer.com/article/10.1007\%2Fs10143-010-0259-4

9 Pérez-Ortiz JM, Tranque P, Burgos M, Vaquero CF and Llopis $\mathrm{J}$ : Glitazones induce astroglioma cell death by releasing reactive oxygen species from mitochondria: modulation of cytotoxicity by nitric oxide. Mol Pharmacol 72: 407-417, 2007. http://molpharm.aspetjournals.org/content/72/2/407.long

10 Gabryś D, Dörfler A, Yaromina A, Hessel F, Krause M, Oertel $\mathrm{R}$ and Baumann M: Effects of lovastatin alone or combined with irradiation on tumor cells in vitro and in vivo. Strahlenther Onkol 184: 48-53, 2008. http://link.springer.com/article/ 10.1007\%2Fs00066-008-1805-7.

11 Bababeygy SR, Polevaya NV, Youssef S, Sun A, Xiong A, Prugpichailers T, Veeravagu A, Hou LC, Steinman L and Tse V: HMG-CoA reductase inhibition causes increased necrosis and apoptosis in an in vivo mouse glioblastoma multiforme model. Anticancer Res 29: 4901-4908, 2009. http://ar.iiarjournals.org/ content/29/12/4901.long

12 Coras R, Hölsken A, Seufert S, Hauke J, Eyüpoglu IY, Reichel M, Tränkle C, Siebzehnrübl FA, Buslei R, Blümcke I and Hahnen E: The peroxisome proliferator-activated receptorgamma agonist troglitazone inhibits transforming growth factor beta- mediated glioma cell migration and brain invasion. Mol Cancer Ther 6: 1745-1754, 2007. http://mct.aacrjournals.org/ content/6/6/1745. long

13 Papi A, Tatenhorst L, Terwel D, Hermes M, Kummer MP, Orlandi $\mathrm{M}$ and Heneka MT: PPAR gamma and RXR gamma ligands act synergistically as potent antineoplastic agents in vitro and in vivo glioma models. Neurochem 109: 1779-1790, 2009. http://onlinelibrary.wiley.com/doi/10.1111/j.1471-4159. 2009.06111.x/abstract

14 Spagnolo A, Glick RP, Lin H, Cohen EP, Feinstein DL and Lichtor T: Prolonged survival of mice with established intracerebral glioma receiving combined treatment with peroxisome proliferator-activated receptor-gamma thiazolidinedione agonists and interleukin-2-secreting syngeneic/allogeneic fibroblasts. J Neurosurg 106: 299-305, 2007. http://thejns.org/ doi/abs/10.3171/jns.2007.106.2.299?url_ver=Z39.88-2003\& rfr_id=ori:rid:crossref.org\&rfr_dat=cr_pub\%3dpubmed

15 Grommes C, Karlo JC, Caprariello A, Blankenship D, Dechant A and Landreth GE: The PPAR $\gamma$ agonist pioglitazone crosses the blood-brain barrier and reduces tumor growth in a human xenograft model. Cancer Chemother Pharmacol 71: 929-936, 2013. http://link.springer.com/article/10.1007\%2Fs00280-0132084-2

16 Tapia-Pérez JH, Kirches E, Mawrin C, Firsching R and Schneider T: Cytotoxic effect of different statins and thiazolidinediones on malignant glioma cells. Cancer Chemother Pharmacol 67: 1193-1201, 2011. http://link.springer.com/article/ 10.1007\%2Fs00280-010-1535-2

17 Yao CJ, Lai GM, Chan CF, Cheng AL, Yang YY and Chuang SE: Dramatic synergistic anticancer effect of clinically achievable doses of lovastatin and troglitazone. Int J Cancer 118: 773-779, 2006. http://onlinelibrary.wiley.com/doi/10.1002/ ijc.21361/abstract
18 Barth RF and Kaur B: Rat brain tumor models in experimental neuro-oncology: the C6, 9L, T9, RG2, F98, BT4C, RT-2 and CNS1 gliomas. J Neurooncol 94: 299-312, 2009. https://www.ncbi.nlm. nih.gov/pmc/articles/PMC2730996/

19 Floyd JS, Heckbert SR, Weiss NS, Carrell DS and Psaty BM: Use of administrative data to estimate the incidence of statinrelated rhabdomyolysis. JAMA 307: 1580-1582, 2012. http://jamanetwork.com/journals/jama/fullarticle/1148145

20 Hamelin BA and Turgeon J: Hydrophilicity/lipophilicity: relevance for the pharmacology and clinical effects of HMGCoA reductase inhibitors. Trends Pharmacol Sci 19: 26-37, 1998.

21 Mason RP, Walter MF, Day CA and Jacob RF: Intermolecular differences of 3-hydroxy-3-methylglutaryl coenzyme a reductase inhibitors contribute to distinct pharmacologic and pleiotropic actions. Am J Cardiol 96: 11F-23F, 2005. http:// www.ajconline.org/ article/S0002-9149(05)00954-9/pdf

22 Araújo FA, Rocha MA, Mendes JB and Andrade SP: Atorvastatin inhibits inflammatory angiogenesis in mice through down regulation of VEGF, TNF-alpha and TGF-beta1. Biomed Pharmacother 64: 29-34, 2010. http://www.sciencedirect.com/ science/article/pii/S0753332209000444

23 Larner J, Jane J, Laws E, Packer R, Myers C and Shaffrey M: A phase I-II trial of lovastatin for anaplastic astrocytoma and glioblastoma multiforme. Am. J Clin Oncol 21: 579-583, 1998.

24 López-Aguilar E, Sepúlveda-Vildósola AC, Betanzos-Cabrera Y, Rocha-Moreno YG, Gascón-Lastiri G, Rivera-Márquez H, Wanzke-del-Angel V, Cerecedo-Díaz F and de la Cruz-Yañez H: Phase II study of metronomic chemotherapy with thalidomide, carboplatin-vincristine-fluvastatin in the treatment of brain stem tumors in children. Arch Med Res 39(7): 655-662, 2008.

25 Mercurio S, Padovani L, Colin C, Carré M, Tchoghandjian A, Scavarda D, Lambert S, Baeza-Kallee N, Fernandez C, Chappé $\mathrm{C}$, André $\mathrm{N}$ and Figarella-Branger D: Evidence for new targets and synergistic effect of metronomic celecoxib/fluvastatin combination in pilocytic astrocytoma. Acta Neuropathol Commun 1:17, 2013. https://www.ncbi.nlm.nih.gov/pmc/ articles/PMC3893468/

26 Kostapanos MS, Elisaf MS and Mikhailidis DP: Pioglitazone and cancer: angel or demon? Curr Pharm Des 19: 4913-4929, 2013.

27 Gehring S, Tapia-Pérez JH, Kirches E, Firsching R, Keilhoff G, Schneider $\mathrm{T}$ and Mawrin C: Cytotoxic effects of statins and thiazolidinediones on meningioma cells. J Neurooncol 102: 383393, 2011. http://link.springer.com/article/10.1007\%2Fs11060010-0351-1

28 Yano M, Matsumura T, Senokuchi T, Ishii N, Murata Y, Taketa K, Motoshima H, Taguchi T, Sonoda K, Kukidome D, Takuwa Y, Kawada T, Brownlee M, Nishikawa T and Araki E: Statins activate peroxisome proliferator-activated receptor gamma through extracellular signal-regulated kinase $1 / 2$ and p38 mitogen-activated protein kinase-dependent cyclooxygenase-2 expression in macrophages. Circ Res 100: 1442-1451, 2007. http://circres.ahajournals.org/content/100/10/1442.long

29 Greenwood J, Steinman L and Zamvil SS: Statin therapy and autoimmune disease: from protein prenylation to immunomodulation. Nat Rev Immunol 6: 358-370, 2006. https://www.ncbi.nlm.nih.gov/pmc/articles/PMC3842637/

30 Ganesan A, Crum-Cianflone N, Higgins J, Qin J, Rehm C, Metcalf J, Brandt C, Vita J, Decker CF, Sklar P, Bavaro M, Tasker S, Follmann D and Maldarelli F: High dose atorvastatin 
decreases cellular markers of immune activation without affecting HIV-1 RNA levels: results of a double-blind randomized placebo controlled clinical trial. J Infect Dis 203: 756-764, 2011. https://www.ncbi.nlm.nih.gov/pmc/articles/ PMC3071124/

31 Kuipers HF, Biesta PJ, Groothuis TA, Neefjes JJ, Mommaas AM and van den Elsen PJ: Statins affect cell-surface expression of major histocompatibility complex class II molecules by disrupting cholesterol-containing microdomains. Hum Immunol 66: 653-665, 2005.

32 Kuipers HF, Rappert AA, Mommaas AM, van Haastert ES, van der Valk P, Boddeke HW and Biber KP: Simvastatin affects cell motility and actin cytoskeleton distribution of microglia. Glia 53: 115-123, 2006. http://onlinelibrary.wiley.com/doi/10.1002/ glia.20269/abstract

33 Weitz-Schmidt G: Lymphocyte function-associated antigen-1 blockade by statins: molecular basis and biological relevance. Endothelium 10: 43-47, 2003.

34 Gruenbacher G, Gander H, Nussbaumer O, Nussbaumer W, Rahm A and Thurnher M: IL-2 costimulation enables statinmediated activation of human NK cells, preferentially through a mechanism involving $\mathrm{CD}^{2} 6^{+}$dendritic cells. Cancer Res 70 : 9611-9620, 2010. http://cancerres.aacrjournals.org/content/ 70/23/9611.long

35 Coniglio SJ and Segall JE: Review: molecular mechanism of microglia stimulated glioblastoma invasion. Matrix Biol 32: 372380, 2013. http://www.sciencedirect.com/science/article/ pii/S0945053X13001030

36 Nielsen SF, Nordestgaard BG and Bojesen SE: Statin use and reduced cancer-related mortality. N Engl J Med 367: 1792-1802, 2012. http://www.nejm.org/doi/full/10.1056/NEJMoa1201735

37 Ferris JS, McCoy L, Neugut AI, Wrensch M and Lai R: HMG CoA reductase inhibitors, NSAIDs and risk of glioma. Int $\mathrm{J}$ Cancer 131: E1031-E1037, 2012. http://onlinelibrary.wiley.com/ doi/10.1002/ijc.27536/abstract.
38 Gaist D, Andersen L, Hallas J, Toft Sørensen H, Schrøder HD and Friis S: Use of statins and risk of glioma: a nationwide casecontrol study in Denmark. Br J Cancer 108(3): 715-720, 2013. http://www.nature.com/bjc/journal/v108/n3/full/bjc2012536a.html

39 Gaist D, Hallas J, Friis S, Hansen S and Sørensen HAT: Statin use and survival following glioblastoma multiforme. Cancer Epidemiol 38: 722-727, 2014.

40 Mohebbi N, Khoshnevisan A, Naderi S, Abdollahzade S, Salamzadeh J, Javadi M, Mojtahedzadeh M and Gholami K: Effects of atorvastatin on plasma matrix metalloproteinase-9 concentration after glial tumor resection; a randomized, double blind, placebo controlled trial. Daru 22: 10, 2014. http:// darujps.biomedcentral.com/articles/10.1186/2008-2231-22-10

41 Wood WG, Müller WE and Eckert GP: Statins and Neuroprotection: Basic Pharmacology Needed. Mol Neurobiol 50: 214-220, 2014. http://link.springer.com/article/10.1007\% 2Fs 12035-014-8647-3

42 Posvar EL, Radulovic LL, Cilla DD Jr., Whitfield LR and Sedman AJ: Tolerance and pharmacokinetics of single-dose atorvastatin, a potent inhibitor of HMG-CoA reductase, in healthy subjects. J Clin Pharmacol 36: 728-731, 1996. http://onlinelibrary.wiley.com/doi/10.1002/j.15524604.1996.tb04242.x/abstract

43 Saheki A, Terasaki T, Tamai I and Tsuji A: In vivo and in vitro blood-brain barrier transport of 3-hydroxy-3-methylglutaryl coenzyme A (HMG-CoA) reductase inhibitors. Pharm Res 11: 305-311, 1994.
Received October 12, 2016

Revised October 29, 2016

Accepted November 2, 2016 